\title{
A Key to the Australian Genera of Eumeninae (Hymenoptera: Vespidae)
}

\author{
JAMES M. CARPENTER ${ }^{1}$ (D) AND GRAham R. BROWN ${ }^{2}$ (iD \\ ${ }^{1}$ Division of Invertebrate Zoology, American Museum of Natural History, \\ Central Park West at 79th Street, New York, NY 10024, United States of America \\ ${ }^{2}$ Museum and Art Gallery of the Northern Territory, \\ GPO Box 4646, Darwin, NT 0801, Australia; and \\ ${ }^{2}$ Visiting Scientist, CSIRO Land and Water, \\ Private Mail Bag 44, Winnellie, NT 0822, Australia; and \\ ${ }^{2}$ University Fellow, Research Institute for Environment and Livelihoods, \\ Charles Darwin University, Darwin, NT 0909, Australia
}

\begin{abstract}
An illustrated identification key to the genera of potter wasps occurring in Australia is presented. Hitherto there has been no published key to these genera, making routine identification impossible, and allowing taxonomic study of these wasps to be carried out only by specialists. This has greatly inhibited biological study of these wasps, which are known to exhibit interesting behavioural ecology. For the same reason, their use as biological control agents has scarcely been investigated. And as a result, the conservation status of any of the species is unknown. Our aim is that this key should begin to rectify this situation.
\end{abstract}

\section{Introduction}

Potter wasps or mud wasps are common elements of the Australian Hymenoptera. Comprising the subfamily Eumeninae of the family Vespidae, they are by far the most species rich part of that family worldwide (nearly 4,000 species; see Pickett \& Carpenter, 2010: table 1). Some Australian species can be quite abundant locally, and the mud nests of some of the larger species are a familiar sight. Because they provision their nests with caterpillars (Fig. 49), they are potential biological control agents. Aspects of their behaviour, including nest construction and mating systems, have attracted the interest of evolutionary biologists (Smith \& Alcock, 1980; Matthews \& Matthews, 2004, 2009, 2010).

Nearly 300 species are described from Australia, but the fauna is far from well known, with many undescribed species.
A better understanding of the fauna is greatly hampered by the lack of a basic identification key to the genera. There has been no key to the genera since the only worldwide monograph of the Vespidae, de Saussure (1852-1858), which is now of course well out of date. When Giordani Soika (1962) broke up the old, broad concept of the genus Odynerus Latreille, 1802, the key he provided was characteristically limited almost entirely to the genera he described or in which he described new species (and was in Italian). The key did not include such common Australian taxa as Abispa Mitchell, 1838, or Paralastor de Saussure, 1856, so it does not even correspond to a key to the tribe Odynerini in the sense of Hermes et al. (2014). Giordani Soika (1969) published a key to Australian genera of the tribe Zethini (as subfamily Discoeliinae; also in Italian), but there has never been a modern key to genera of the tribe Eumenini, let alone a key including all three tribes. 
A key to all the Australian genera is presented here. The generic classification is quite different from that in the catalogue by Cardale (1985); the differences are explained in the new catalogue of Australian Eumeninae (Carpenter $\&$ Brown, 2021). There has even been one further change since the new catalogue was published: Lopes et al. (2021) have more recently reduced Ischnocoelia Perkins, 1908, to a subgenus of Zethus Fabricius, 1804. Besides those changes, the key includes one genus, Pseumenes Giordani Soika, 1935, which has not been hitherto recorded from Australia. This is based on an apparently undescribed species seen by one of us (JMC). The key does not include another genus, Pachodynerus de Saussure, 1870, of which one species has been found nesting in the Brisbane airport. Should the genus become widely established in Australia, it would key out to couplet 30, and, like the genus Epsilon de Saussure, 1855, it has a projecting submarginal carina. It is easily distinguished from that genus by possessing a humeral carina running obliquely on the pronotum (see figs. 52 and 57 in Carpenter \& Garcete-Barrett, 2003).

The current generic classification of Australian potter wasps is as fragmented as generic taxonomy of this group elsewhere in the world (see discussion in Carpenter \& Cumming, 1985), and we do not necessarily agree with it. But progress in the taxonomy of these wasps cannot be made without a basic means of identification.

\section{Key to genera}

Terminology largely follows Carpenter \& Cumming (1985). The metasomal terga and sterna are abbreviated as TI, SI, etc. Tribal assignments are according to the concepts of Hermes et al. (2014).

$1 \quad$ Midtibia with 2 spurs tribe Zethini 2

Midtibia with 1 spur

2 Metasomal segment I more than twice as long as high in profile, with height half or less that of II (Figs 1-2); propodeal orifice narrowly rounded dorsally (Figs 12-13)

Metasomal segment I less than twice as long as high in profile, with height half or more than that of II (Fig. 3); propodeal orifice more or less pointed dorsally (Fig. 14)

3 Hindwing jugal lobe absent Australozethus Giordani Soika

Hindwing jugal lobe present

4 Submarginal carina projecting as pointed lobe above propodeal valvula (Fig. 2); propodeum with median longitudinal carina; palpal formula 6-4 Elimus de Saussure

Submarginal carina not projecting as pointed lobe above propodeal valvula (Fig. 1); propodeum without median longitudinal carina; palpal formula 3-3 Zethus Fabricius (subgenus Ischnocoelia Perkins)

5 Tegula enormous, as large as disc of scutellum (Fig. 3) Macrocalymma Perkins

Tegula smaller than disc of scutellum (Figs 4-5) 6

6 Propodeal valvula elongate and rectangular to subrectangular (Fig. 13) Deuterodiscoelius Dalla Torre 
7 Metasoma petiolate: segment I with height half or less that of II in profile, and at least twice as long as high, usually longer (Figs 1-2), in dorsal view with width half or less that of II, and at least twice as long as wide (Fig. 27) 8

Metasoma not petiolate: segment I with height more than half that of II in profile, much less than twice as high as wide (Figs 4-7), in dorsal view with width more than half that of II, much less than twice as long as wide (Figs 10-11, 19-20)

tribe Odynerini (part) .....12

8 Propodeum dorsally with elongate fovea from which carina runs to orifice, with more or less dentiform projections above valvulae (Figs 27-28); tegula with narrow posterior lobe which equals length of parategula (Fig. 16)

Propodeum without elongate fovea or dentiform projections; tegula convex posteriorly not equalling length of parategula (Fig. 15)

9 TI with transverse carina basally; epicnemial carina present

(Fig. 29); female with cephalic foveae (Fig. 46) Ectopioglossa Perkins

TI not carinate; epicnemial carina absent; female without cephalic foveae Pseumenes Giordani Soika

10 TII with translucent apical lamella, clearly separated from disc by preapical thickening (Figs 2-3) Eumenes Latreille

TII without apical lamella 11

11 TI with section after spiracles shorter than section before spiracles Delta de Saussure

TI with section after spiracles longer than section before spiracles (Fig. 49) Phimenes Giordani Soika

12 Forewing with second submarginal cell petiolate or nearly so (Fig. 22); male antenna with number of articles variable, usually fewer than 13 Paralastor de Saussure

Forewing with second submarginal cell not petiolate (Figs 21, 23); male antenna usually with 13 articles 13

13 Propodeum with basal acarinarium formed by deep, polished fossae (Figs 19-20)

Propodeum without deep fossae 15

14 Acarinarium formed by deep median cavity and two small, lateral fossae (Fig. 20); metasomal segment I subcylindrical, in dorsal view petiolate for nearly half its length before expanding abruptly to a width slightly more than half that of segment II (Figs 11, 20) Acarozumia Bequaert

Acarinarium formed by two submedian fossae (Fig. 19); metasomal segment I sessile, in dorsal view about as wide as II (Figs 10, 19) 
15 Metanotum tuberculate (Figs 37-40); if lateral tubercles weak then propodeum with blunt dorsolateral ridges behind metanotum (Fig. 37) 16

Metanotum without tubercles (Figs 35-36) 18

16 Metanotum trituberculate (Fig. 38); forewing with prestigma more than $4 \times$ the length of the pterostigma (Fig. 21) Abispa Mitchell

Metanotum bituberculate (Fig. 37, 39-40); prestigma much shorter relative to pterostigma, usually less than length of latter (Fig. 23)

17 Propodeum with blunt dorsolateral ridges behind metanotum (Fig. 37); SII in profile truncate anteriorly (Fig. 5); axillary fossa in dorsal view oval, wide (Fig. 39)

Diemodynerus Giordani Soika

Propodeum without superior ridges; SII in profile flat or evenly convex anteriorly (Figs 6-7); axillary fossa in dorsal view narrower than long, slit-like (Fig. 40) Pseudabispa van der Vecht

18 Tegula with posterior margin not reaching tip of parategula (Fig. 17); forewing with prestigma $\geq$ half the length of the pterostigma, measured along posterior part, usually nearly equal; axillary fossa in dorsal view narrower than long, often slit-like (Fig. 40)

Tegula with posterior margin equalling or exceeding tip of parategula posteriorly (Figs 16, 18); forewing with prestigma $<$ half the length of the pterostigma, measured along posterior part (Fig. 23); axillary fossa in dorsal view at least as wide as long (Fig. 39), oval

19 Colour bright metallic; metasomal segment I subcylindrical, in dorsal view petiolate for about half its length before expanding abruptly to a width slightly more than half that of segment II (Fig. 11) Eudiscoelius Friese

Colour not bright metallic; metasomal segment I sessile, about as wide as II (Fig. 10)

20 Scutum posteriorly and scutellum mesally impunctate; metanotum somewhat compressed medially; male midfemur basally emarginate (Fig. 25) Rhynchium Spinola

Scutum and scutellum punctate; metanotum not compressed medially; male midfemur not basally emarginate 21

21 Metanotum flat; propodeal dorsum raised shelf-like to same level (Fig. 30); male SVII with one or two tubercles Allorhynchium van der Vecht

Metanotum angled; propodeal dorsum not at same level

(Fig. 29); male SVII without tubercles

22 Propodeum with transverse dorsal carinae; TI with faint transverse carina at anterior declivity (Fig. 7); clypeus widely emarginate (Fig. 41)

Pararrhynchium de Saussure

Propodeum and TI without carinae; clypeus not widely

emarginate (Fig. 42) Anterhynchium de Saussure 
23 TI with two transverse carinae; anterior face of pronotum with two small, close set, deeply impressed medial foveae (Fig. 24) ...

TI without two transverse carinae, occasionally with one; anterior face of pronotum without two close set, deeply impressed foveae

24 Female with cephalic foveae in raised, transversely oval area that is wider than ocellar triangle and densely setose (Fig. 45); male SVII with apex depressed, subtruncate (Fig. 9); male midfemur often toothed medially (Fig. 26)

Pseudalastor Giordani Soika

Female cephalic foveae if in raised area, then narrower than ocellar triangle (Fig. 46); male SVII rounded apically (Fig. 8) and male midfemur not toothed

25 Vertex with low, elongate tubercles above eyes (Figs 47-48) ..... Parifodynerus Giordani Soika

Vertex without tubercles (Figs 45-46) 26

26 Female with cephalic foveae in raised oval area that is narrower than ocellar triangle (Fig. 46); male antennal hook minute, articles globose (Fig. 43)

Flammodynerus Giordani Soika

Female cephalic foveae not in raised area; male antennal hook

well developed (Fig. 44)

27 Metasomal segment I subsessile, in dorsal view narrower than II

(Fig. 11)

Metasomal segment I sessile, in dorsal view about as wide as II

(Fig. 10)

28 Metanotum convex, forming smooth surface with propodeum (Fig. 32)

Leptomenoides Giordani Soika

Metanotum dorsally angled (Fig. 31) Antamenes Giordani Soika

29 Metanotum flat or smoothly convex; propodeum with dorsal surface at about same level as metanotum (Fig. 35), dorsal teeth may be present (Fig. 36) Stenodyneriellus Giordani Soika

Metanotum angled; propodeum not raised shelf-like to same level, without dorsal teeth

30 Propodeum depressed medially, with lateral teeth (Figs 36-37);

female with one cephalic fovea; usually smaller species Australodynerus Giordani Soika

Propodeum usually unarmored, if with teeth not so depressed; female with two cephalic foveae; usually larger species

31 Tegula long, with posterior lobe covering parategula and pointing medially Knemodynerus Blüthgen

Tegula shorter, with posterior lobe not covering parategula, never pointing medially 32

32 Propodeum with submarginal carina projecting as rounded lobe above valvula (Fig. 33) Epsilon de Saussure

Propodeum with submarginal carina not differentiated from valvula (Fig. 34) Euodynerus Dalla Torre 

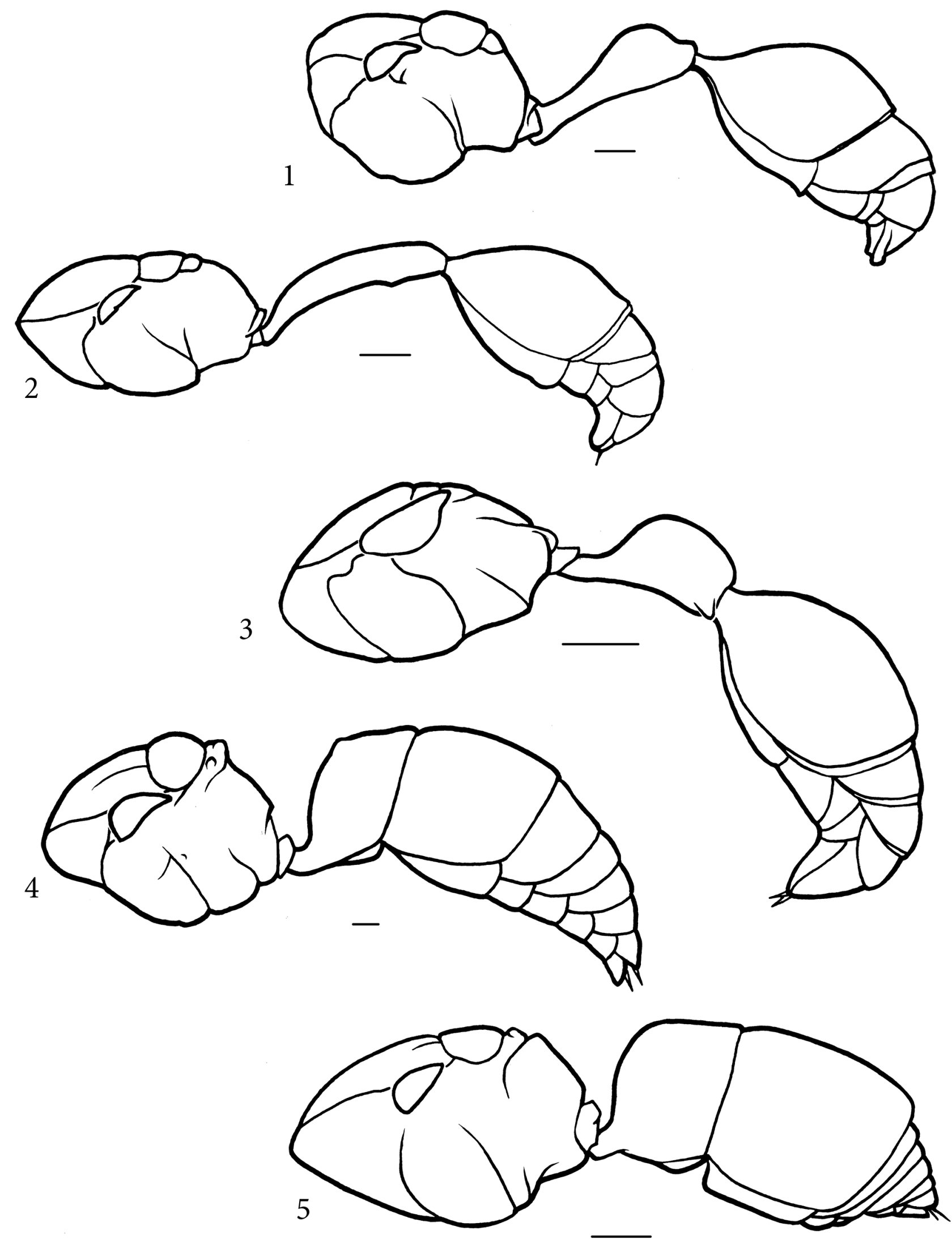

Figures 1-5. Lateral views of mesosoma and metasoma: (1) Australozethus continentalis Giordani Soika; (2) Elimus mackayensis MeadeWaldo; (3) Macrocalymma smithianum Perkins; (4) Abispa ephippium (Fabricius); (5) Diemodynerus pseudacarodynerus Giordani Soika. Scale $=1.0 \mathrm{~mm}$. 

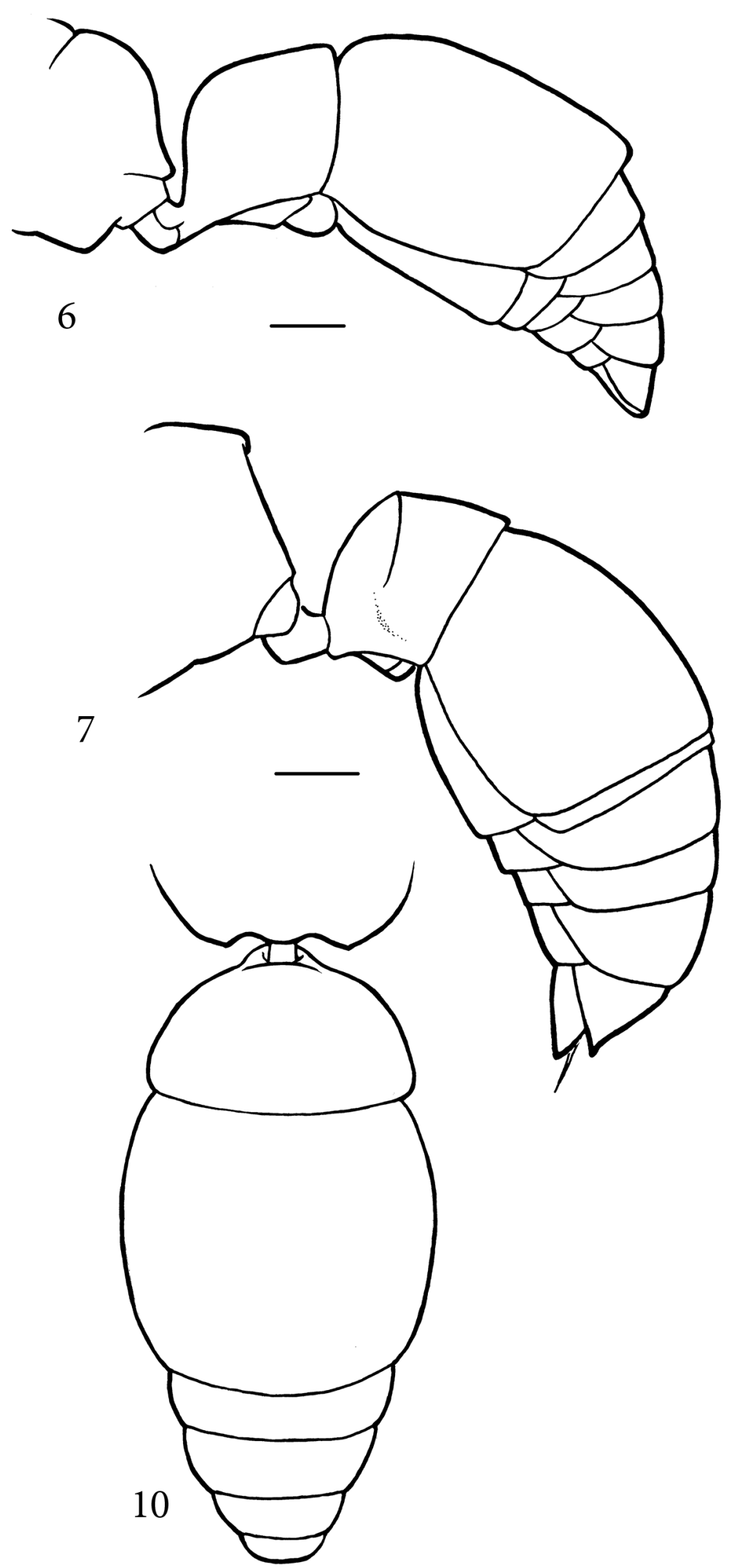
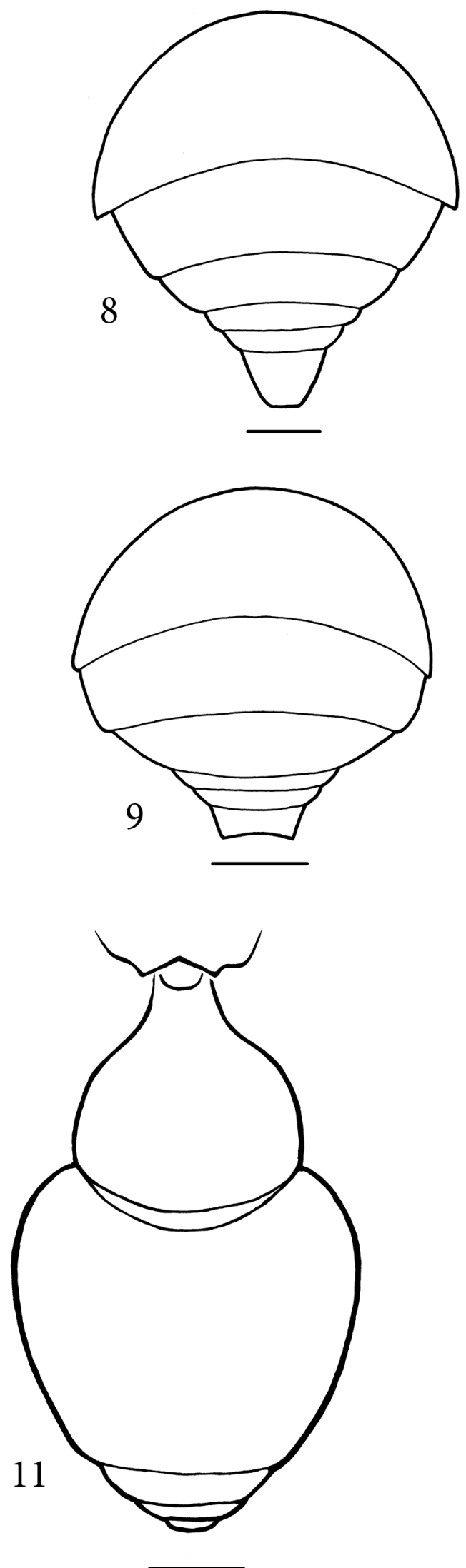

Figures 6-11. Lateral views of metasoma: (6) Acarodynerus dietrichianus (de Saussure); (7) Pararrhynchium sp. Dorsal views of male metasomal segments II-VII: (8) Parifodynerus alariformis (de Saussure); (9) Pseudalastor sp. Dorsal views of metasoma: (10) Stenodyneriellus bicoloratus (de Saussure); (11) Eudiscoelius jacinthae (Gribodo). Scale = $1.0 \mathrm{~mm}$. 

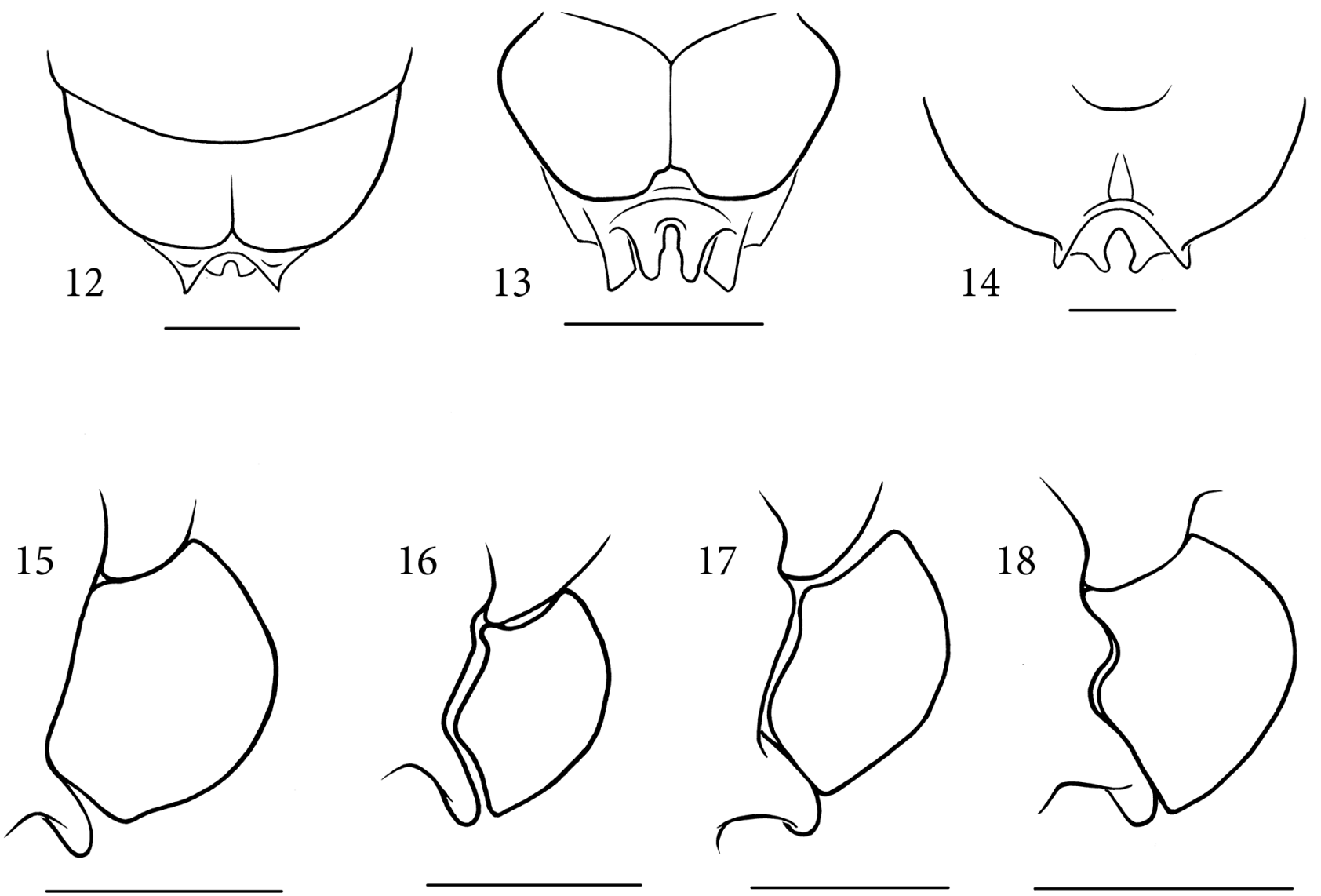

Figures 12-18. Posterior views of propodeum: (12) Elimus australis de Saussure; (13) Zethus (Ischnocoelia) fulvus (von Schulthess); (14) Pachycoelius sp. Tegula: (15) Phimenes incola (Giordani Soika); (16) Ectopioglossa polita australensis (Meade-Waldo); (17) Rhynchium superbum de Saussure; (18) Parifodynerus alariformis (de Saussure). Scale $=1.0 \mathrm{~mm}$. 

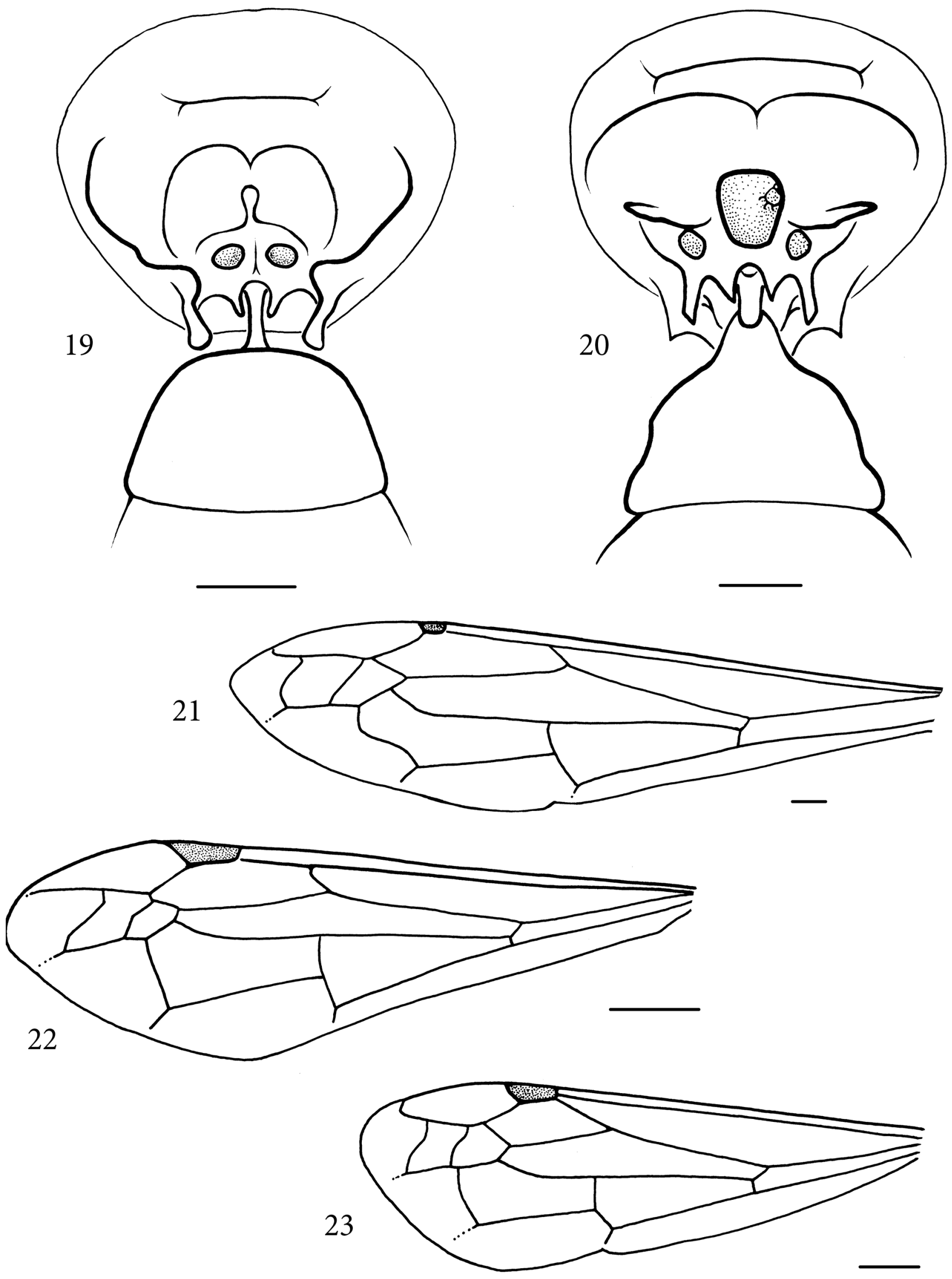

Figures 19-23. Posterior views of propodeum: (19) Acarodynerus acarophilus Giordani Soika; (20) Acarozumia amaliae (de Saussure). Forewings: (21) Abispa ephippium (Fabricius); (22) Paralastor sp.; (23) Diemodynerus pseudacarodynerus (Giordani Soika). Scale=1.0 mm. 

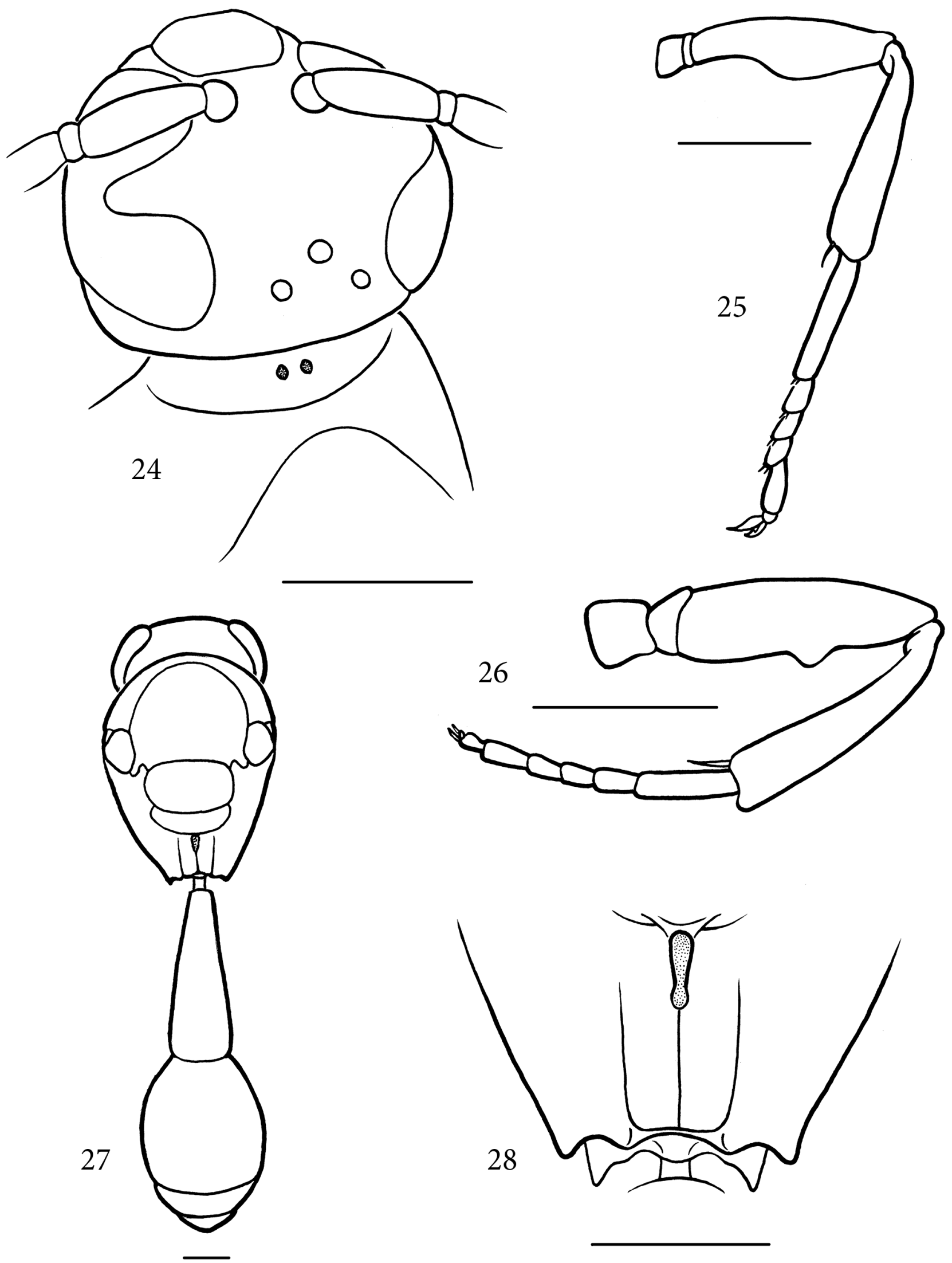

Figures 24-28. (24) Dorsal views of head and pronotum, Subancistrocerus monstricornis (Giordani Soika). Male midlegs: (25) Rhynchium superbum de Saussure; (26) Pseudalastor sp. (27-28) Ectopioglossa polita australensis (Meade-Waldo): (27) dorsal view; (28) posterior view of propodeum. Scale $=1.0 \mathrm{~mm}$. 

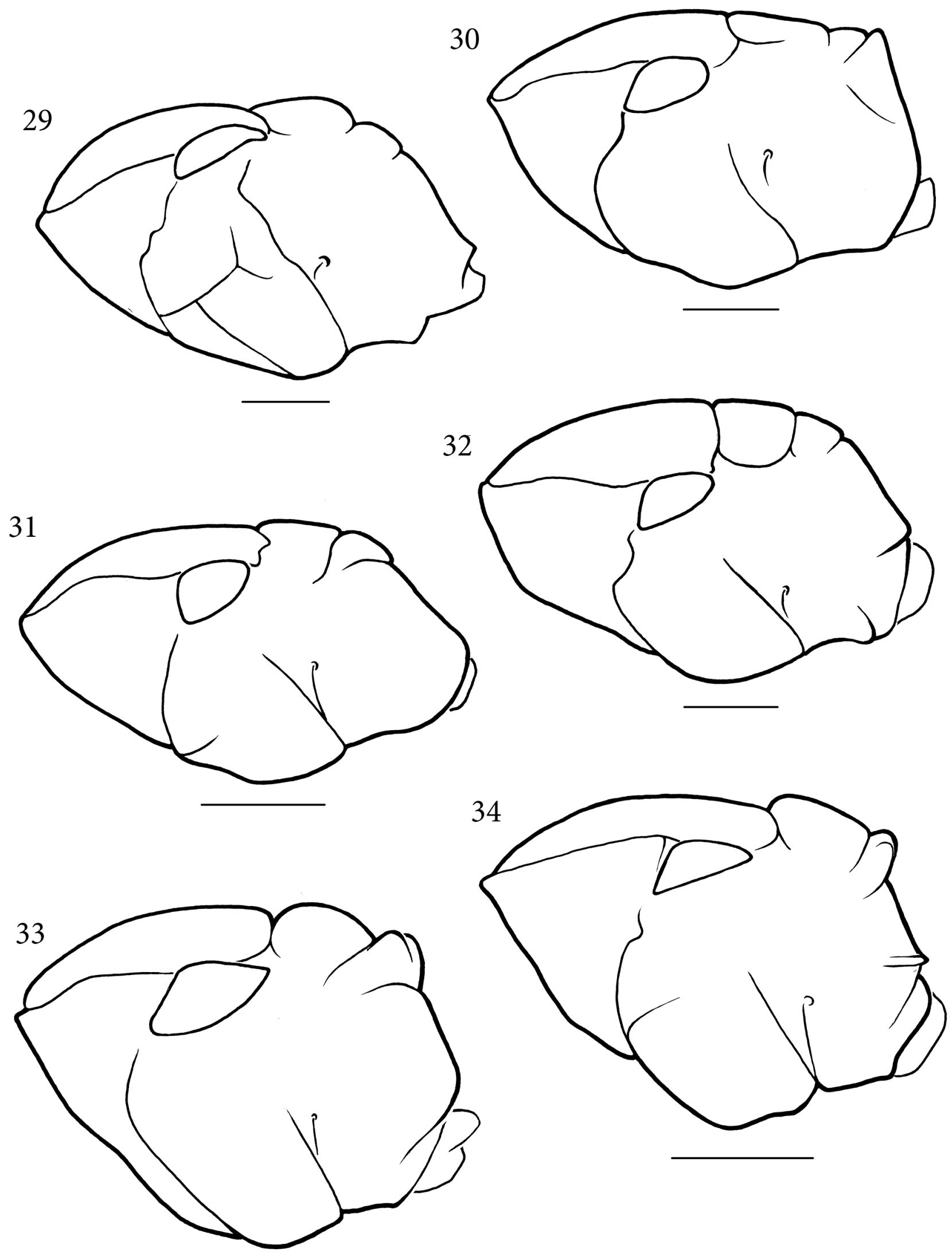

Figures 29-34. Lateral views of mesosoma: (29) Ectopioglossa polita australensis (Meade-Waldo); (30) Allorhynchium argentatum (Fabricius); (31) Antamenes hostilis Giordani Soika; (32) Leptomenoides mackayensis Giordani Soika; (33) Epsilon laboriosum (Smith); (34) Euodynerus angulatus (de Saussure). Scale $=1.0 \mathrm{~mm}$. 

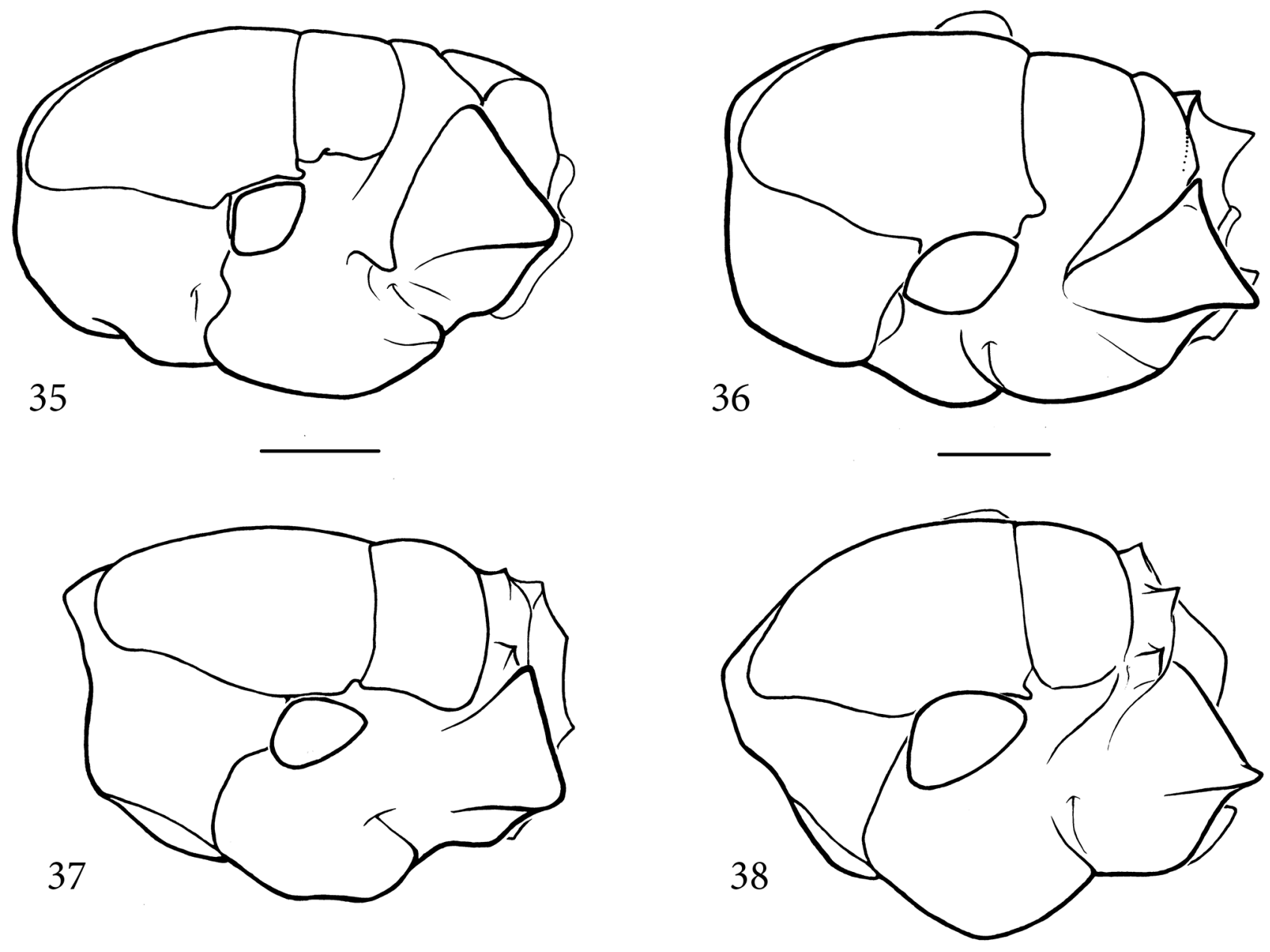

39
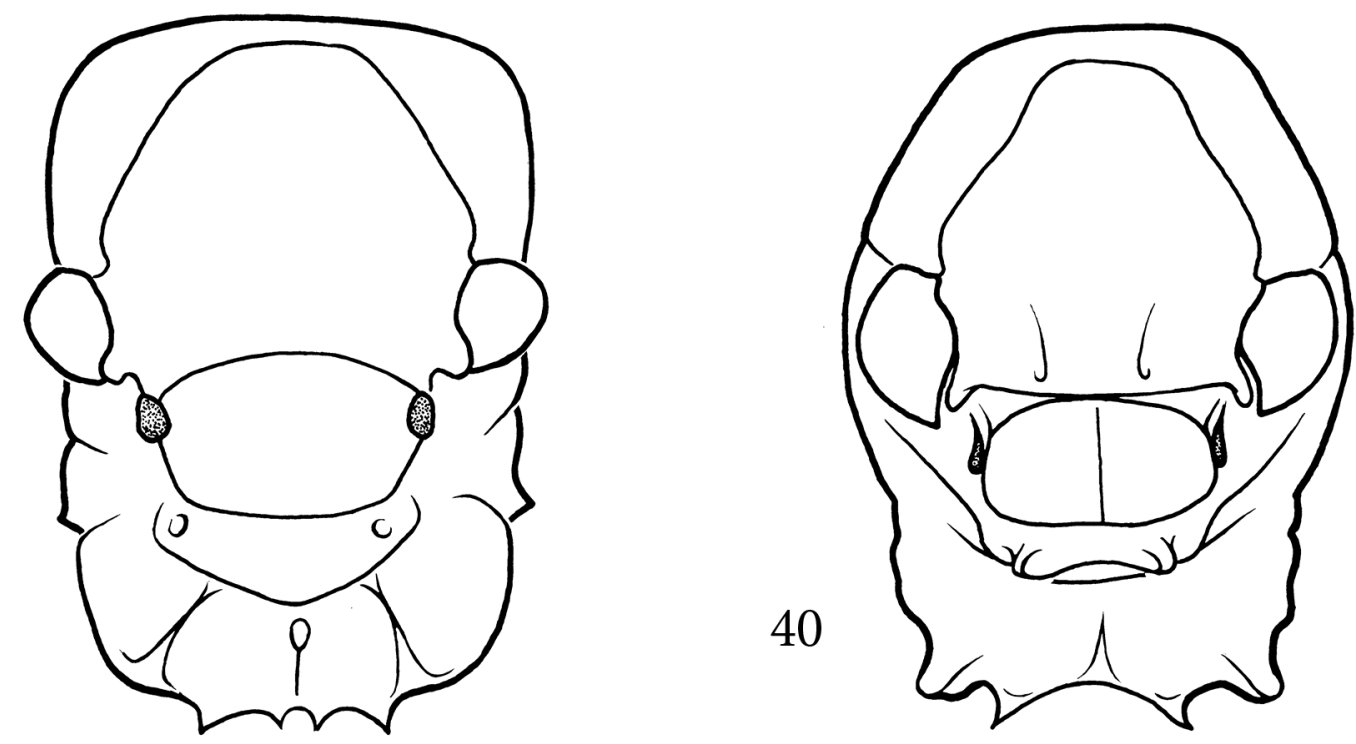

Figures 35-40. Oblique dorsal views of mesosoma: (35) Stenodyneriellus bicoloratus (de Saussure); (36) Stenodyneriellus occidentatus (Giordani Soika); (37) Diemodynerus diemensis (de Saussure); (38) Abispa ephippium (Fabricius). Dorsal views of mesosoma: (39) Diemodynerus pseudacarodynerus (Giordani Soika); (40) Pseudabispa paragioides (Meade-Waldo). Scale = $1.0 \mathrm{~mm}$. 


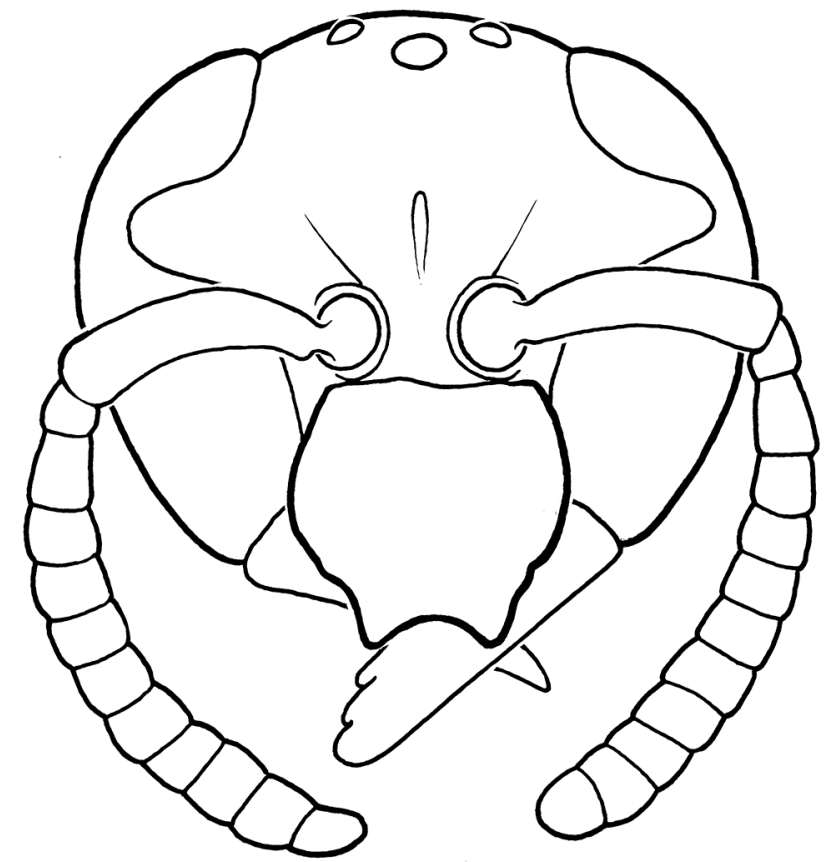

41
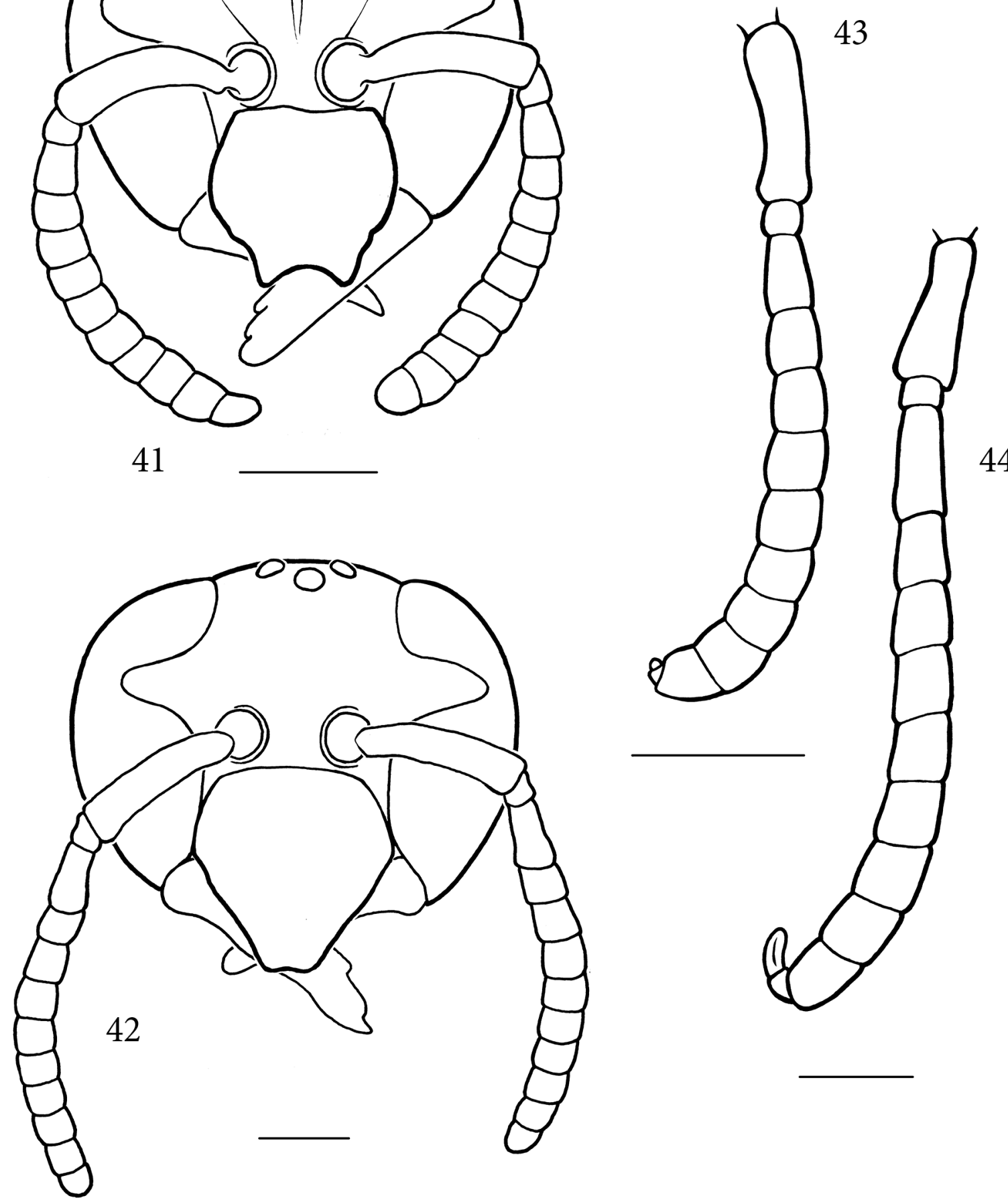

Figures 41-44. Frontal views of head: (41) Pararrhynchium sp.; (42) Anterhynchium flavolineatum (Smith). Male antennae: (43) Flammodynerus flammiger (de Saussure); (44) Deuterodiscoelius pseudospinosus (Giordani Soika)? Scale $=1.0 \mathrm{~mm}$. 


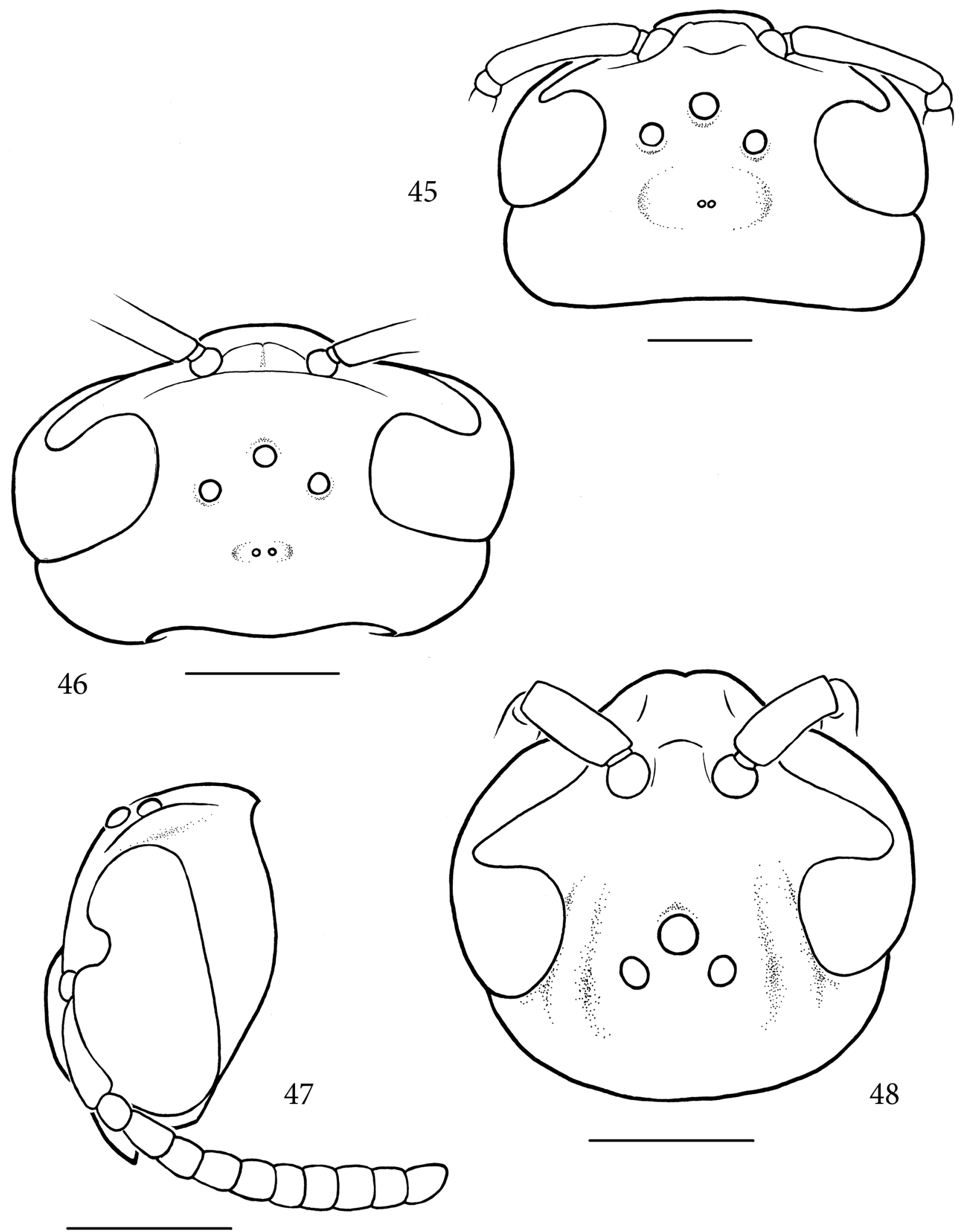

Figures 45-48. Dorsal views of head: (45) Pseudalastor cavifemur Giordani Soika; (46) Ectopioglossa polita australensis (Meade-Waldo); (47-48) Parifodynerus alariformis (de Saussure): (47) lateral view of head; (48) dorsal view of head. Scale $=1.0 \mathrm{~mm}$. 


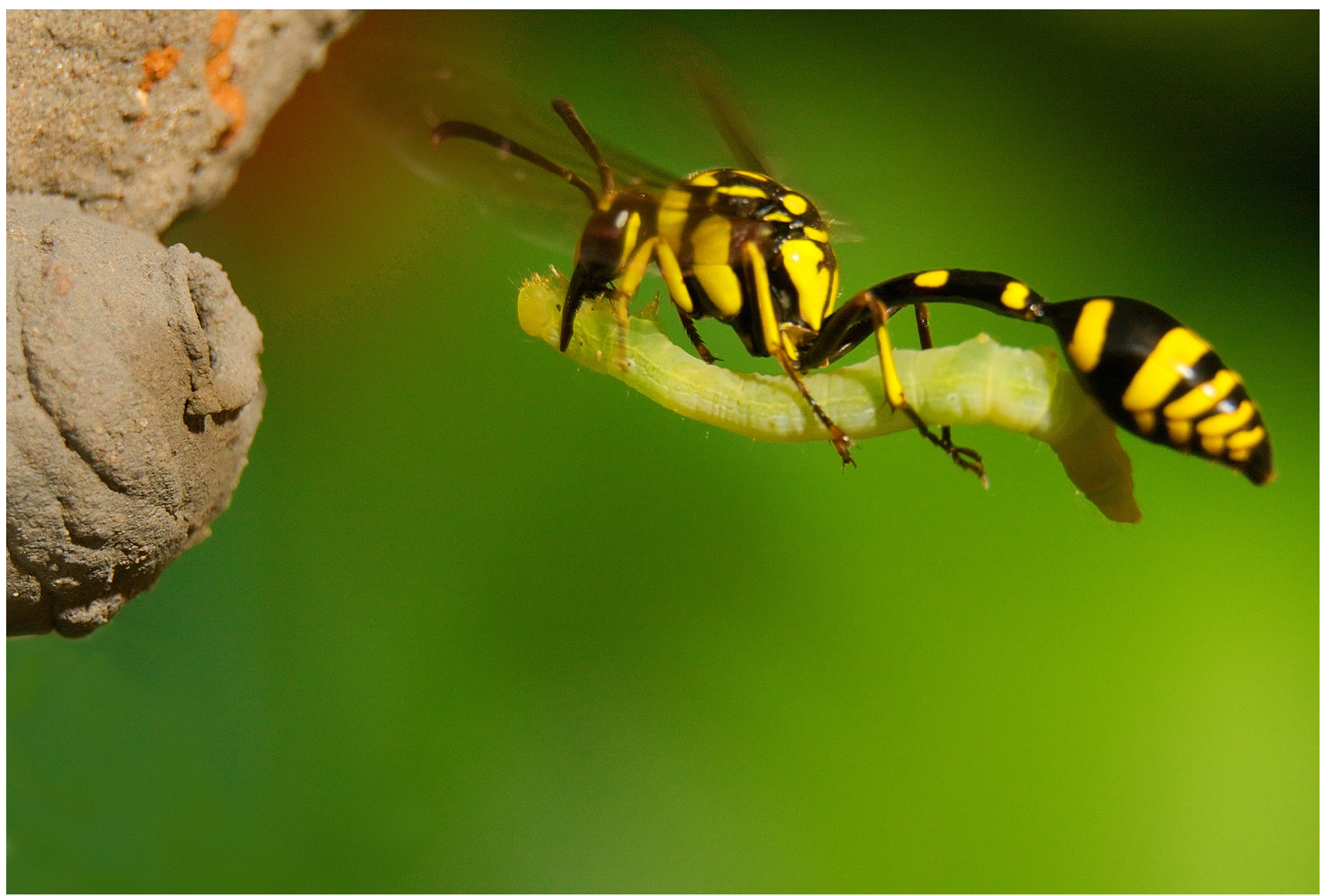

Figure 49. Phimenes arcuatus (Fabricius), with prey and nest.

Acknowledgements. We thank Tissa Ratnayeke for the photograph and Molly Rightmyer for the drawings. JMC would like to acknowledge the late Geoff Holloway and Dan Bickel, of the Australian Museum, who were the first to welcome him to Australia during his first visit in 1986, and who made the collection of that museum available for study. That study began the path to construction of this key.

\section{References}

Cardale, J. C. 1985. Vespoidea and Sphecoidea. Zoological Catalogue of Australia 2: 150-303.

Carpenter, J. M., and G. R. Brown. 2021. Catalogue of the Australian Eumeninae (Hymenoptera: Vespidae). Zootaxa 4919(1): 1-68.

https://doi.org/10.11646/zootaxa.4919.1.1

Carpenter, J. M., and J. M. Cumming. 1985. A character analysis of the North American potter wasps (Hymenoptera: Vespidae; Eumeninae). Journal of Natural History 19(5): 877-916. https://doi.org/10.1080/00222938500770551

Carpenter, J. M., and B. R. Garcete-Barrett. 2003. A key to the neotropical genera of Eumeninae (Hymenoptera: Vespidae). Boletín del Museo Nacional de Historia Natural del Paraguay 14(1-2): 52-73. [Dated 2002, published 2003.]

Giordani Soika, A. 1962. Gli Odynerus sensu antiquo del continente australioano e della Tasmania. Bollettino del Museo Civico di Storia Naturale di Venezia 14: 57-202. [Dated 1961, published 1962.]

Giordani Soika, A. 1969. Revisione dei Discoeliinae australiani. Bollettino del Museo Civico di Storia Naturale di Venezia 19: 25-100.

Hermes, M. G., G. A. R. Melo, and J. M. Carpenter. 2014. The higher-level phylogenetic relationships of the Eumeninae
(Insecta, Hymenoptera, Vespidae), with emphasis on Eumenes sensu lato. Cladistics 30(5): 453-484.

https://doi.org/10.1111/cla.12059

Lopes, R. B., J. M. Carpenter, and F. B. Noll. 2021. Cladistic analysis of Zethus Fabricius, 1804 (Hymenoptera, Vespidae): a new subgeneric classification. Journal of Hymenoptera Research 82: 253-283. https://doi.org/10.3897/jhr.82.65760

Matthews, R. W., and J. R. Matthews. 2004. Biological notes on three species of giant Australian mason wasps, Abispa (Hymenoptera: Vespidae: Eumeninae). Journal of the Kansas Entomological Society 77(4): 573-583. https://doi.org/10.2317/E20.1

Matthews, R. W., and J. R. Matthews. 2009. Nesting behavior of Abispa ephippium (Fabricius) (Hymenoptera: Vespidae: Eumeninae): extended parental care in an Australian mason wasp. Psyche 851694: 1-15. https://doi.org/10.1155/2009/851694

Matthews, R. W., and J. R. Matthews. 2010. Interspecific nest parasitism by Pseudabispa paragioides, a solitary Australian wasp. Journal of Insect Science 10(160): 1-12. https://doi.org/10.1673/031.010.14120

Pickett, K. M., and J. M. Carpenter. 2010. Simultaneous analysis and the origin of eusociality in the Vespidae (Insecta: Hymenoptera). Arthropod Systematics and Phylogeny 68(1): 3-33.

Saussure, H. F. de. 1852-1858. Etudes sur la Famille des Vespides. Vols. 1-3. V. Paris: Masson \& Geneva: J. Cherbuliez. https://doi.org/10.5962/bhl.title.39973

Smith, A. P., and J. Alcock. 1980. A comparative study of the mating systems of Australian eumenid wasps (Hymenoptera). Zeitschrift für Tierpsychologie 53: 41-60. https://doi.org/10.1111/j.1439-0310.1980.tb00732.x 